\title{
Penisin Yüzeyel Dorsal Ven Trombozunun Retrospektif Analizi
}

\author{
Retrospective Analysis of Penile in Superficial Dorsal Vein Thrombosis
}

\author{
Tuncay Taș', Basri Çakıroğlu², Ersan Arda³ \\ 1 Istanbul Esenyurt University, Department of Urology, Esenyurt, Istanbul, Turkey \\ 2 Hisar Intercontinental Hospital, Department of Urology, Istanbul, Turkey \\ 3 Trakya University, Department of Urology, Edirne, Turkey
}

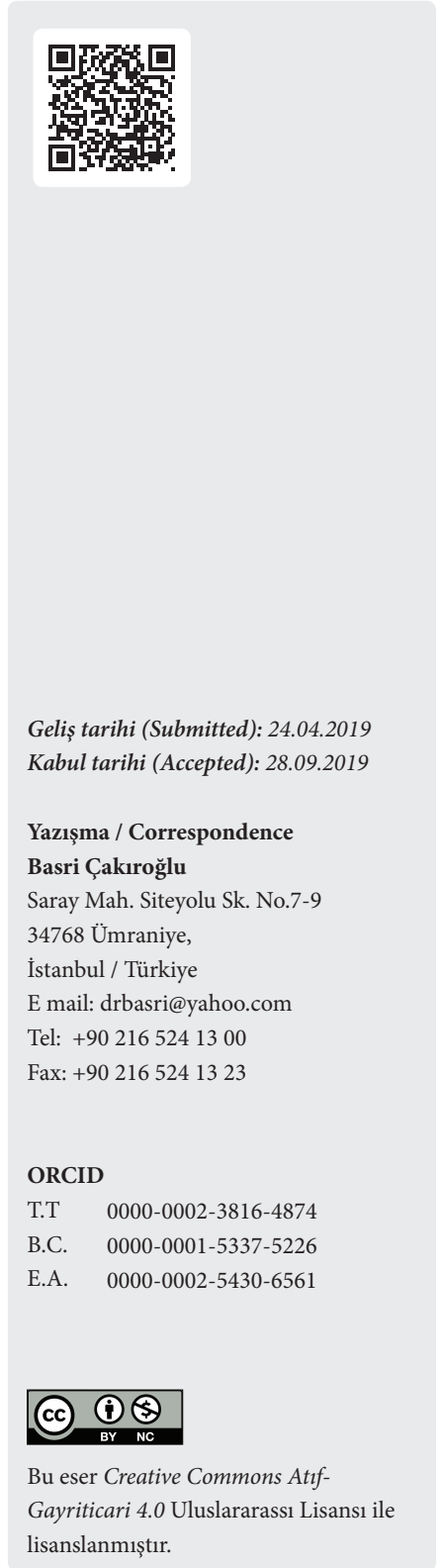

\section{Özet}

Amaç: Penil yüzeysel venöz tromboz nadir ve az bilinen iyi huylu genital durumdur; literatürdeki en geniş olgu serileri 25 ve 30 hastayı tanımlamaktadır.

Gereç ve Yöntemler: Ocak 2009 ile Ocak 2018 arasında üroloji polikliniğinde penil mondor hastalığı (PMH) tanısı ile tedavi ve takibi yapılan 23 hastanın verileri retrospektif olarak değerlendirildi. Hastalar için anamnez, yüzeyel ven renkli doppler ultrasonografi ve rutin laboratuvar analiz (kan sayımı, elektrolitler ve pıhtılaşma testleri) uygulandi. Seküel aktiviteden kaçınma NSAID, anti-koagülan ajanlar ve topical Arnica montana kullanımını içeren konservatif yaklaşım uyguland. Tedavinin 1. hafta ve 3., 5., 8. haftalarında ve 3. ayda takip muayeneleri yapıldı. Klinik iyileşme değerlendirildi.

Bulgular: Çalışmamızda hastalarımızın ortalama yaşı 42.4 (SD:11.12) medyan yaşı 44, yaş aralığı 22 ile 66 aralığındaydı. Hastaların BMI 28.5 (SD: 2.48) ve aralığ 22.91 ile 34.31 idi. Hastaların semptomlarının başlangıcı ve kabulleri arası süre ortalama 9.35 (SD: 13.42) medyanı 4 gün olup semptomlarının başlangıcı ve kabulleri arası en az süre 1 gün en uzun süre 60 gündü. Hastalar1mızın tamamı peniste ağrısız palpable kord semptomu ile kliniğimize başvurmuştu. Hastalarımızın 20 'sinde tromboze damar dişardan belirgindi. Tromboz çapı ortalama $3.09 \pm 1.04 \mathrm{~mm}$ ve medyanı 3 mm (dağılım 1.8-5) idi. Tikalı damarların çapı 1.3 ile $4.7 \mathrm{~mm}$ arasında değişiyordu. Standart labaratuvar testleri normaldi. 8 hastada lezyonların koronal sulkusun hemen altında sulkusa paralel sert lezyon olduğu ve diğer 15 hastada dorsal peniste cord-like lezyon olduğu görüldü. Venöz renkli doppler ultrasonografi sonuçları tüm hastalar için benzerdi. Doppler ultrasonografide yüzeyel venin lümeninde renk dolgusu ve akış spektrumu gözlenmedi. Etyolojide 8 hastada uzamıș

\section{Abstract}

Objective: Penile superficial venous thrombosis is a rare and little-known benign genital condition. The largest series of penile superficial venous thrombosis cases in literature include 25 and 30 patients.

Material and Methods: A retrospective evaluation was made of the data of 23 patients who were treated and followed up for a diagnosis of PMD in the Urology Outpatient Clinic between January 2009 and January 2018. Anamnesis, superficial vein color Doppler ultrasonography and routine laboratory analysis (i.e. blood count, electrolytes and coagulation tests) were applied to the patients. A conservative approach was provided the use of NSAIDs, anti-coagulant agents and topical Arnica Montana, and avoidance of the sexual activity. Follow-up examinations were made after $1,3,5$, and 8 weeks and 3 months of treatment. Clinical improvement was evaluated.

Results: The age of the patients in the study was mean $42.4 \pm 11.12$ years and median 44 years (range, 22-66 years). The mean BMI of the patients was 28.5 \pm 2.48 (range, 22.91-34.31). The mean period between the onset of symptoms and presentation was $9.35 \pm 13.42$ days, median 4 days, and range, 1-60 days. On presentation, all the patients had painless palpable cord symptoms. In 20 patients, the thrombotic vein could not be determined externally. The diameter of the thrombosis was mean $3.09 \pm 1.04 \mathrm{~mm}$ and median $3 \mathrm{~mm}$ (range, $1.8-5)$. The diameter of the obstructed veins ranged from 1.3 to $4.7 \mathrm{~mm}$. No pathological findings were determined in the standard laboratory tests of all 23 patients. The lesions were found to be parallel to the sulcus below the coronal sulcus in 8 patients, and 15 patients had a cord-like lesion on the dorsal penis. The venous color Doppler ultrasound results were similar for all the patients. No color filling and flow spectrum was observed in 
cinsel aktivite, 5 hastada uzamıs mastürbasyon, 3 hasta da vakum erreksiyon cihazı, 7 hasta idiopatik izlendi. Hastaların sadece birinde daha önce PMH öyküsü gelişimi mevcuttu. Konservatif tedavi kullanılarak 23 vakanın 21'inde düzelme elde edildi. 2 olguda trombektomi gerekli oldu. Takipte 2 hastada tekrarlayan atak görüldü.

Sonuç: Penil Mondor hastalığı oldukça nadir olmakla birlikte, hastalarda belirgin anksiyeteye sebep olur. Çalışmamızda etyolojide travmanın etkinliğini ortaya koymuş olduk. Çoğunlukla konservatif tedavi ile kendiliğinden düzelir, nadiren konservatif ile düzelmeyen hastalarda cerrahi tedavi gerekebilir.

Anahtar Kelimeler: Mondor hastalığı, penis, yüzeyel venöz tromboflebit the lumen of the superficial vein on color Doppler US. In the etiology, prolonged sexual activity was determined in 8 patients, prolonged masturbation in 5 , the use of a vacuum erection device in 3 , and 7 patients were idiopathic. Only 1 patient had a history of PMD development. Conservative treatment was applied to 21 of the 23 cases. Thrombectomy was required in 2 cases. At follow-up examination, two recurrent episodes were observed.

Conclusions: Penile Mondor's disease is rare, but causes noticeable anxiety in patients. The results of this study demonstrate the effect of trauma in the etiology. Patients generally recover with conservative treatment, and occasionally surgical treatment may be necessary.

Keywords: Mondor's disease, penis, thrombophlebitis

\section{INTRODUCTION}

The disease now known as Mondor's disease was first described by Fagge in 1869, followed by reports of 4 patients with inflammatory cord-like lesions on the anterolateral chest wall by Henri Mondor in 1939 (1).

The disease is now often referred to as Mondor's disease as Henri Mondor was the first to define the penile form. In 1955, Braun-Falco reported superficial penile vein involvement in diffuse thrombophlebitis of the abdominal wall and in 1958 Helm and Hodge first described isolated superficial dorsal penile vein thrombosis (2-4). Penile superficial venous thrombosis is a rare and little-known benign genital condition. The largest series of penile superficial venous thrombosis cases in literature include 25 and 30 patients. Penile superficial venous thrombosis is often a benign condition. For research to be able to contribute to literature, careful etiological evaluation is needed to avoid exceptional causes (5). There are a limited number of studies showing that penile Mondor's disease (PMD) affects sexually active men of any age and the findings have not revealed any specific reason. However, possible causes of the disease have been suggested of trauma, previous surgery, sclerotherapy, malignancies, radiotherapy, bleeding coagulation problems, and inflammatory or infectious processes. Although there are few case reports, the main etiological cause is accepted as trauma, and the most common cause of penile trauma in literature is prolonged sexual intercourse $(2,6,7)$. Studies have reported that other causes of penile trauma include vacuum devices, masturbation and compression of the penis during the surgery (8).
The pathogenesis is not clearly known but predisposing factors, such as endothelial damage, venous stasis and hypercoagulability, have been reported to play a role in the development of PMD. Clinical findings in PMD include palpable cord, pain, tenderness, swelling, erythema and edema. Pain may be intermittent or continuous form and is often aggravated during erection (9).

In most cases, the diagnosis is reached based on clinical findings. Color Doppler sonography is useful in the diagnosis of thrombosis and the monitoring of the resolution of thrombosis (10).

Magnetic resonance angiography findings can also be used to diagnose thrombosis in the superficial dorsal penile vein (11).

As the studies in literature have reported that self-limiting and non-progressive thrombophlebitis is seen in PMD, anticoagulant drugs are not routinely administered in the acute and subacute period. Treatment is usually planned for the inflammatory process. A conservative approach, including treatment of sexual activity, drug-free monitoring, NSAID and antibiotic use, is often preferred. The aim of this multicentric study was to present the results of treatment of isolated superficial penile vein thrombosis.

\section{Patients and Methods}

A retrospective evaluation was made of the data of 23 patients who were treated and followed up for a diagnosis of PMD in the Urology Outpatient Clinic between January 2009 and January 2018. The mean duration of observation was 5.4 months (range, 3-2 months). On presentation at the clinic all patients 
had complaints of a cord-like lesion on the penis surface. Anamnesis, superficial vein color Doppler ultrasonography and routine laboratory analysis (i.e. blood count, electrolytes and coagulation tests) were applied to the patients. A conservative approach was provided for 14 days, including the use of NSAIDs, anti-coagulant agents and topical Arnica Montana, and avoidance of the sexual activity. Follow-up examinations were made after $1,3,5$, and 8 weeks and 3 months of treatment. Clinical improvement was evaluated.

\section{RESULTS}

The age of the patients in the study was mean 42.4 \pm 11.12 years and median 44 years (range, 22 - 66 years). The mean BMI of the patients was $28.5 \pm 2.48$ (range, 22.91-34.31). The mean period between the onset of symptoms and presentation was $9.35 \pm 13.42$ days, median 4 days, and range, 1 - 60 days. On presentation, all the patients had painless palpable cord symptoms. In 20 patients, the thrombotic vein could not be determined externally. The diameter of the thrombosis was mean $3.09 \pm 1.04 \mathrm{~mm}$ and median $3 \mathrm{~mm}$ (range, 1.8 -5 ). The diameter of the obstructed veins ranged from 1.3 to $4.7 \mathrm{~mm}$.

No pathological findings were determined in the standard laboratory tests of all 23 patients All the patients had been surgically circumcised. In 3 patients, mild pain was experienced during erection and no pain was reported by any other patients. Acute inflammation with erythema and oedema was determined in 5 patients. The lesions were found to be parallel to the sulcus below the coronal sulcus in 8 patients (Figure-1), and 14 patients had a cord-like lesion on the dorsal penis. Excessive tension in the thrombosis was reported by 3 patients. In 1 patient there was extension up to the suprapubic region (Figure-2). The venous color Doppler ultrasound results were similar for all the patients. The venous color Doppler ultrasound results were similar for all the patients.

No color filling and flow spectrum was observed in the lumen of the superficial vein on color Doppler US. (Figure-3)

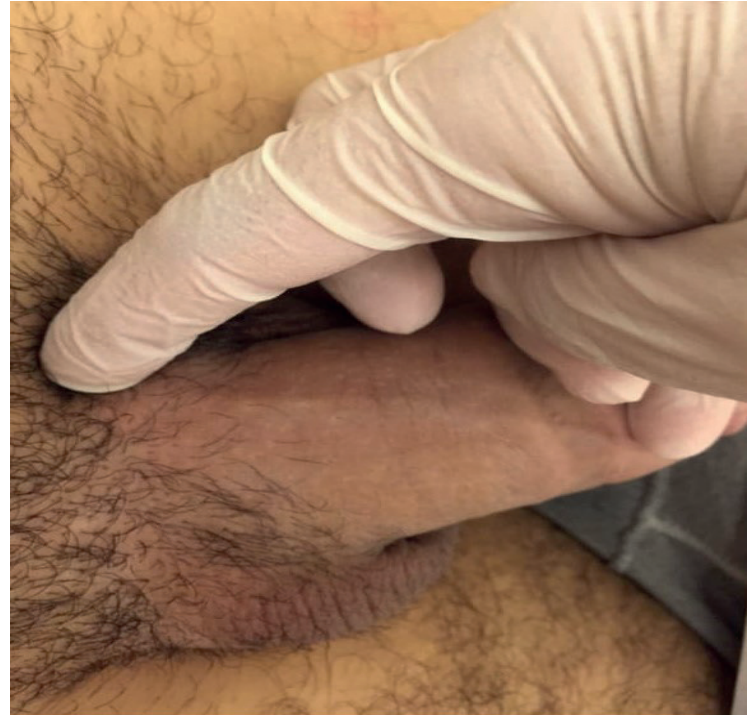

Figure 1. The lesion appearing parallel to the sulcus under the coronal sulcus

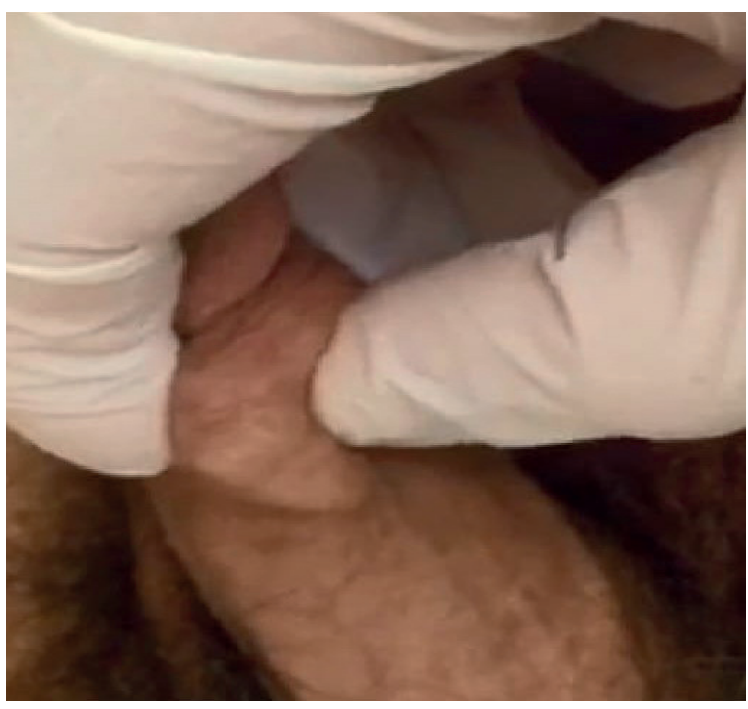

Figure 2. The lesion extending to the suprapubic region

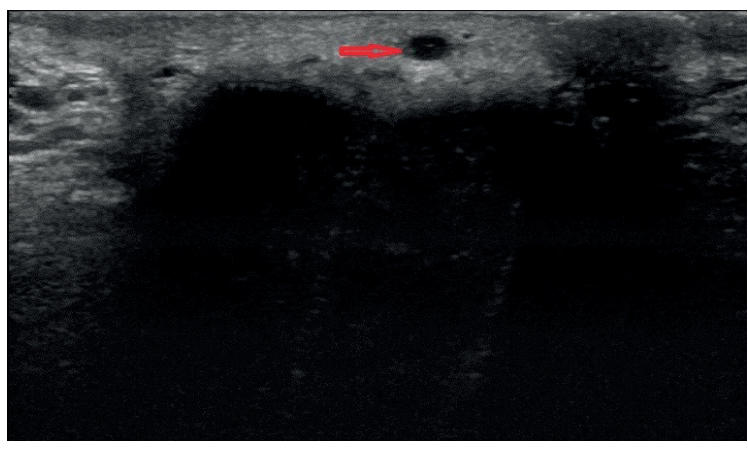

Figure 3. No color filling and flow spectrum was observed in the lumen of the superficial vein on color Doppler US. 
In the etiology, prolonged sexual activity was determined in 8 patients, prolonged masturbation in 5 , the use of a vacuum erection device in 3 , and 7 patients were idiopathic. Only 1 patient had a history of PMD development. Conservative treatment was applied to 21 of the 23 cases. Thrombectomy was required in 2 cases. At the end of the first week, 3 patients showed a decrease in the density of the lesion and reported a decrease in their symptoms. There was a regression in the lesion in the second week of the follow-up period in patients who did not need a surgical procedure. The time to response to treatment was $12 \pm$ 1 days (range, 10-15 days). In 20 patients, the lesion completely disappeared, and in 2 patients the lesion had not regressed in the 3rd month. On the superficial venous Doppler ultrasound, the venous diameter of these 2 lesions was $3.6 \mathrm{~mm}$ and $4.7 \mathrm{~mm}$, respectively. These patients underwent surgery. At the 6-month follow-up examination, no recurrent episodes were observed. No recurrence was observed in the 6-month follow-up of the patients applied with surgery.

\section{DISCUSSION}

Published data on the superficial penile vein thrombosis are rare and consist mostly of single case studies (3). Although the actual incidence is unknown, it is thought to be higher than reported. While this disease may affect men of any age, studies have reported that usually men aged 20 - 40 years are at the highest risk (12). In the current study, the age range was higher. The etiological factors of the current series were consistent with the findings of other studies. Prolonged sexual activity, the use of a vacuum device and prolonged masturbation were observed in 15 patients. These findings suggest that trauma may be the main factor. There have also been case reports of penile Mondor's disease after inguinal hernia repair and sub-inguinal varicocelectomy (3). None of the current patients had a history of previous surgery or cancer. The most significant study in literature of PMD related to a previous surgical procedure was 3 cases of PMD reported in 231 cases of long saphenous vein surgery (7). In that series, the incidence exceeded the $1 \%$ risk level (3). In another study, in which PMD was determined following a surgical procedure, the findings showed that there was no specific etiology and PMD may have developed due to pelvic venous stasis and crushing of the penis on the operating table (13). If none of the known etiological factors is present, penile Mondor's disease is considered idiopathic. In the 23 cases of the current series, 7 patients were accepted as idiopathic. The laboratory tests were normal and no underlying risk factors were found. Previous studies have revealed that antithrombin 3 , protein-C and protein-S deficiencies may be present in these idiopathic cases $(3,4,14)$. Late presentation at the clinic due to anxiety and embarrassment is common and this was observed in the current series. Clinical information on recurrent episodes of PMD is limited. In 1 of the current patients, recurrent thrombosis was seen to be associated with traumatic sexual activity. This finding is consistent with two other studies in literature. Generally, PMD is a self-limiting disease and most cases resolve within 4 to 6 weeks, with re-permeabilization in 9 weeks (15).

Progression of thrombosis is not usually seen and routine anticoagulation therapy is not recommended. Creams that contain heparin and anti-inflammatory drugs are used in the sub-acute and chronic stages (16). The general approach is limited to supportive care, including pain management, hot compresses, and avoidance of sexual activity. Conservative primary therapy, consisting of pain relief and anti-inflammatory drugs, opioid analgesics, topical heparin and antiphlogistic applications is usually sufficient. If the thrombosis persists despite conservative treatment, surgical thrombectomy or superficial dorsal vein resection may be required. In the current study, the mean length of the thrombophlebitis of the 2 patients who underwent surgery was 3.5 and the average length of thrombophlebitis was 3.05 in the 21 patients who did not undergo surgery.

\section{CONCLUSION}

Penile Mondor's disease is rare, but causes noticeable anxiety in patients. The results of this study demonstrate the effect of trauma in the etiology. Patients generally recover with conservative treatment, and occasionally surgical treatment may be necessary.

\section{Funding}

The authors declare that there is no funding. 


\section{Conflict of Interest Statement}

The authors declare that there is no conflict of interest.

\section{REFERENCES}

1. Laroche JP, Galanaud J, Labau D, et al. Mondor's disease: what's new since 1939?. Thromb Res 2012; 130: S56-S58

2. Katz $\mathrm{R}$ and Blachar A. Superficial dorsal penile vein thrombosis (Mondor's disease). Harefuah 1997 Apr 15;132(8):544-5, 607.

3. Al-Mwalad M, Loertzer H, Wicht A, et al. Subcutaneous penile vein thrombosis (Penile Mondor's Disease): pathogenesis, diagnosis, and therapy. Urology. 2006; 67:586-588.

4. Özkan B, Coskuner ER, Turk A, Akkus E, Yalçın V. Penile Mondor disease and its effect on erectile function: results of 30 patients. Urology 2015 Jan;85(1):113-7.)

5. Zidani H, Foughali $M$ and Laroche JP. Superficial venous thrombosis of the penis: penile Mondor's disease? A case report and literature review. J Mal Vasc. 2010 Dec; 35 (6): $352-4$

6. Pittaka M, Fotiou E, Dionysiou M, et al. Penile Mondor's disease in a patient treated with radical chemoradiation for anal cancer. Oxf Med Case Reports. 2017 Aug 2;2017(8):omx036. doi: 10.1093/omcr/omx036. eCollection 2017 Aug.

7. McLaren AJ, Riazuddin N and Northeast AD. Mondor meets Trendelenburg: penile vein thrombosis after varicose vein surgery. J R Soc Med 2001; 94:292-293.
8. Jung YH and Ryu DS. Mondor's Disease of the Penis Mistaken for Penile Fracture. Urogenit Tract Infect. 2016 Apr;11(1):39-41 doi.org/10.14777/uti.2016.11.1.39

9. Sasso F, Gulino G, Basar M, et al. Penile Mondors disease: an underestimated pathology. Br J Urol 1996; 77:729-732. 8.

10. Shapiro RS. Superficial dorsal penile vein thrombosis (penileMondor's phlebitis): ultrasound diagnosis. J Clin Ultrasound 1996; 24:272-274.

11. Boscolo-Berto R, Iafrate M, Casarrubea G and Ficarra V. Magnetic resonance angiography findings of penileMondor's disease. J Magn Reson Imaging 2009; 30:407-410.

12. Manimala NJ and Parker J. Evaluation and Treatment of Penile Thrombophlebitis (Mondor's Disease). Curr Urol Rep. 2015 Jun;16(6):39.

13. Dobran M Sr, Benigni R Jr, Nasi D Sr and Cantoro D. Penile Mondres' disease after anterolateral retroperitoneal approach for lumbar fracture. BMJ Case Rep 2017 Nov 1; 2017.

14. Girolami A, Simioni P, Scarano L, et al. Venous and arterial thrombophilia. Haematologica 1997; 82: 96 A100.

15. Swierzewski SJ, Denil J and Ohl DA. The management of the penis with Mondor's phlebitis: Superficial dorsal penile and thrombosis. J Urol 1993; 150 (1): 77ews78.

16. Öztürk H. Penile Mondor's disease. Basic Clin Androl 2014 Mar 3;24:5. doi: 10.1186/2051-4190-24-5. eCollection 2014. 